\title{
HUBUNGAN ANTARA MINAT TERHADAP TAYANGAN KEKERASAN DI TELEVISI DENGAN KECENDERUNGAN PERILAKU AGRESIF
}

\author{
Mudhar, S.Psi, M.Si \\ Bimbingan Dan Konseling Universitas Adi Buana Surabaya \\ email: mudhar.bps@gmail.com
}

\begin{abstract}
Abstrak
Penelitian ini bertujuan untuk mengetahui hubungan antara minat terhadap tayangan kekerasan di televisi dengan kecenderungan perilaku agresif. Penelitian ini dilakukan di MTs An-Najah II Sumenep Madura. Sampel yang digunakan sebanyak 87 siswa. Metode analisis yang digunakan adalah dengan menggunakan analisis statistik, yaitu korelasi product moment dari Carl Pearson, hal ini untuk mengungkap hubungan antara minat terhadap tayangan kekerasan di televisi dengan kecenderungan perilaku agresif. Hasil penelitiannya diperoleh nilai $r=$ 0,383 dengan sig. =0,002 (sig. <0,010). Dengan demikian dapat disimpulkan bahwa ada korelasi yang signifikan antara minat terhadap tayangan kekerasan di televisi dengan kecenderungan perilaku agresif.
\end{abstract}

Kata Kunci : Minat terhadap Tayangan Kekerasan, Kecenderungan Perilaku Agresif

\section{PENDAHULUAN}

Tema-tema yang menyoroti

perilaku manusia dalam kaitannya dengan konteks agresivitas selalu menarik untuk diteliti. Banyak problematika di dunia ini yang didasarkan oleh perilaku agresif. Agresif merupakan perilaku yang merugikan, sehingga banyak masyarakat yang menolak jika perilaku agresif muncul.

Akan halnya kenakalan remaja sendiri, dewasa ini menampakkan fenomena yang makin meresahkan dengan perilakunya yang semakin agresif. Keadaan ini tentu sangat memprihatinkan. Berita tentang perkelahian antar individu maupun kelompok seringkali hadir di 
media cetak, radio dan televisi. Tiada hari tanpa pemuatan atau penayangan sosok remaja berbaju seragam yang masih duduk di bangku sekolah tersebut. Topik beritanya tidak hanya meneropong sisi kenakalan remaja, yang biasanya berupa perkelahian antar pelajar, merokok, meminum minuman keras dan mengkonsumsi obat-obatan. Namun juga sampai pada tindakan agresif remaja yang sudah jauh menjurus ke tindak kriminalitas. Bentuk perilaku agresif disini menjadi beragam, dari perkelahian, pengrusakan, perampokan, pembunuhan dan tindak kriminalitas lainnya. Sulit dibayangkan oleh akal sehat, perilaku agresif dalam bentuk membunuh sesama yang dilakukan oleh remaja kadang terkesan dilakukan tanpa perasaan.

Permasalahan di sekitar remaja tentunya tidak terjadi dengan sendirinya dan bukanlah sesuatu yang dikehendaki remaja itu sendiri. Banyak sekali faktor yang mempengaruhi, diantaranya laju arus yang diterima remaja (maraknya info dari media cetak, televisi, internet dan lain-lain). Begitu banyaknya informasi yang mereka terima sehingga remaja kurang dapat membedakan mana informasi yang benar dan mana yang salah. Mereka juga masih kurang bisa membedakan mana informasi yang cocok untuk usia remaja dan mana yang kurang cocok untuk usia mereka. Remaja cenderung menelan begitu saja informasi yang mereka dapatkan, apalagi seandainya informasi yang diperoleh diperkuat kebenarannya oleh kelompoknya, maka remaja akan menelan informasi itu ke dalam dirinya tanpa adanya kontrol dari orang-orang dewasa dilingkungannya yang lebih tahu.

Melalui pemberitaan berbagai media massa, televisi atau mungkin dari pengalaman langsung, sering ditemui masalah-masalah kenakalan remaja yang sangat merugikan masyarakat, sehingga masalah kekerasan yang ditimbulkan remaja tampaknya berlangsung terus dari waktu ke waktu, berulang-ulang atau bahkan berkesinambungan.

Fenomena terakhir pada penghujung tahun 2006, khalayak dikejutkan dengan sering tersiarnya kabar berita mengenai anak-anak 
yang mengalami cedera, bahkan meninggal dunia akibat meniru atau sebagian korban dari kekerasan yang meniru adegan-adegan dalam tayangan smackdown. Dilaporkan sudah jatuh 13 korban dari Bandung, Jakarta dan Yogyakarta. Angka ini tentu tidak menutup kemungkinan dapat bertambah banyak dari hari ke hari atau bahkan ini baru sebagian kecil dari pemberitaan yang terekspos.

Di lain pihak, kenakalan remaja belakangan ini tampak semakin memprihatikan. Bukan hanya kuantitas yang meningkat, tapi juga kualitasnya semakin brutal. Dalam perkelahian antar pelajar misalnya, mereka tidak segan-segan menghabisi lawannya, bahkan yang membuat masyarakat tersentak adalah sumber pemicu perkelahian tersebut kadang kala begitu sederhana. Misalnya, lemparan batu yang tak jelas asal usulnya atau saling bertatapan yang kemudian diartikan sebagai tantangan untuk berkelahi.

Tindakan yang dilakukan oleh remaja-remaja tersebut sudah tidak dapat ditolerir sebagai kenakalan biasa, karena akibat yang ditimbulkannya bersifat sangat negatif dan sering menimbulkan bahaya serta kerugian bagi pihak lain. Menurut Elliot Aronson (dalam Koeswara, 1988) suatu tindakan yang dilakukan oleh individu dengan maksud menyakiti atau melukai individu lain, ini disebut agresi. Jadi perilaku agresi pada remaja dapat menimbulkan kerugian pada diri sendiri maupun orang lain.

Masa remaja merupakan masa-masa yang penuh dengan dinamika dan gejolak bila dibandingkan dengan masa-masa atau fase-fase perkembangan manusia lainnya. Individu pada masa ini sudah tidak mau lagi disebut dan diperlakukan sama dengan anakanak, karena secara fisik fungsi fisiologis mereka sudah sama dengan manusia dewasa, yang ditandai dengan ciri utama yaitu sempurnanya fungsi reproduksi. Sementara itu remaja juga tidak bisa dan belum boleh masuk dalam masa perkembangan manusia dewasa, karena mereka belum matang dalam hal emosional dan belum mampu mandiri secara sosial. 


\begin{abstract}
Remaja sebagai manusia yang sedang berkembang menuju tahap dewasa, mengalami pertumbuhan dan perkembangan. Dalam perkembangannya, remaja memiliki ciri perkembangan yang khas dan menonjol. Masa remaja merupakan masa yang dipenuhi dengan berbagai macam perubahan yang cepat, di mana perubahan disini terkait dengan aspek perkembangan yaitu aspek fisiologis, aspek psikologis dan aspek sosial. Keadaan tersebut akan menyebabkan remaja harus berusaha sangat keras mencapai suatu penyesuaian diri yang harmonis terhadap lingkungan.
\end{abstract} Pada masa remaja, individu meninggalkan kebiasaan tingkah lakunya yang bersifat kekanakkanakan dan membiasakan diri bersikap serta bertingkah laku secara “dewasa”. Disini berarti remaja harus belajar untuk menghindari dan mampu menghadapi masalahmasalahnya tanpa bantuan orang tua atau guru-gurunya.

Stanley hall (dalam Gunarsa, 2000) menyebutkan, masa remaja merupakan masa penuh gejolak emosi dan ketidakseimbangan yang tercakup dalam "storm and stress" (badai dan tekanan), suatu masa dimana ketegangan emosi meninggi sebagai akibat dari perubahan fisik dan kelenjar. Dengan demikian remaja mudah terkena pengaruh oleh lingkungan.

Menurut Gessel (dalam Hurlock, 1996) remaja berusia 14 tahun sering kali mudah marah, mudah dirangsang, emosinya cenderung "meledak", dan tidak berusaha mengendalikan perasaannya. Adapun meningginya emosi terutama karena remaja berada di bawah tekanan sosial dan menghadapi kondisi baru. Sedangkan selama masa kanak-kanak mereka kurang mempersiapkan diri untuk menghadapi keadaan-keadaan itu. Keadaan demikian membuat remaja mengalami ketegangan dan kesulitan untuk menentukan sikap dalam lingkungan dan mengalami masalah yang rumit bagi dirinya.

Remaja pada masa ini sedang meregangkan diri dari ikatan emosional dengan orang tuanya. Mereka sedang membongkar landasan hidup, yang sudah diletakkan orang tuanya sepanjang 
masa anak. Ikatan pribadi pada masa ini sangat penting untuk pembentukan identitas diri. Hubungan dengan orang dewasa dalam lingkungan keluarga, dapat dikatakan sedang di"peti-es"kan.

Seiring dengan bertambahnya usia, remaja pun memiliki minat yang berbeda dengan ketika masih kanak-kanak. Salah satu minat remaja yang muncul adalah minat rekreasi. Pada awal masa remaja, aktivitas permainan dari tahun-tahun sebelumnya beralih dan diganti dengan bentuk rekreasi yang baru dan lebih matang. Berangsur-angsur bentuk permainan yang kekanakkanakan akan menghilang dan menjelang awal masa remaja, pola rekreasi individual hampir sama dengan pola akhir masa remaja dan pola awal masa dewasa. Salah satu minat rekreasi remaja awal adalah menonton televisi.

Minat diartikan sebagai suatu keadaan mental yang menghasilkan respon yang terarahkan kepada suatu situasi atau objek tertentu yang menyenangkan dan memberi kepuasan kepadanya (Semiawan, dalam Wenggi, 2004). Crow \& Crow (dalam Bhatia \& Safaya, 1990), dikatakan bahwa minat merupakan kekuatan pendorong yang mendorong seseorang untuk memperhatikan orang lain, sesuatu benda atau sesuatu aktivitas.

Rustam (1997) mengatakan bahwa dalam melakukan segala kegiatan individu sangat dipengaruhi oleh minat terhadap kegiatan tersebut, sehingga dengan adanya minat yang cukup besar akan mendorong seseorang untuk lebih mencurahkan perhatiannya. Hal tersebut akan meningkatkan pula kesadaran seluruh fungsi jiwanya untuk dipusatkan pada kegiatan yang sedang dilakukannya. Remaja yang berminat pada tayangan tertentu akan lebih tertarik untuk menontonnya.

Minat anak menonton televisi berbeda dengan minat remaja maupun orang dewasa. Anak-anak menonton televisi untuk memenuhi rasa ingin tahunya yang besar sebagai pengisi waktu untuk menghilangkan kebosanan untuk belajar sesuatu dan lainnya. Sementara minat remaja atau orang dewasa adalah untuk mencari hiburan sekalipun mereka sadar 
bahwa sebagian besar tayangan televisi penuh dengan kepalsuan dan kekerasan.

\section{Menonton merupakan} kegiatan yang digemari. Salah satu penelitian mengungkapkan bahwa rata-rata anak dapat duduk di depan televisi kira-kira 4 - 9,5 jam per hari (Yhofita, 2002). Dapat dibayangkan berapa banyak informasi yang diserap oleh anak-anak selama satu hari melalui tayangan televisi. Padahal tidak semua tayangan itu berpengaruh baik bagi anak dan sesuai dengan perkembangan dan kepribadiannya.

Remaja dengan hadirnya sejumlah stasiun televisi memberikan alternatif tontonan atau tayangan yang dapat dinikmati. Programprogram yang berisikan informasi, pendidikan dan hiburan tidak mengambil bagian yang sama dalam pertelevisian. Program-program hiburan dalam bentuk film baik untuk anak-anak atau dewasa cenderung berisi adegan-adegan kekerasan, pembunuhan, kekejaman, pelecehan dan sangat sedikit unsur pendidikannya. Tayangan televisi yang menonjolkan kekerasan dan seksualitas dijadikan sarana produser agar filmnya laku ditonton (Surono \& Teviningrum, 1999).

\section{Kecenderungan}

meningkatnya tindak kekerasan dan perilaku negatif lainnya diduga sebagai dampak dari tayangan kekerasan dalam film, karena media memiliki potensi besar dalam mengubah sikap dan perilaku masyarakat terutama remaja yang relatif mudah terpengaruh oleh lingkungan sekitarnya.

Sebuah penelitian yang dilakukan oleh Berkowitz (dalam Koeswara, 1988) menunjukkan bahwa menonton film-film yang berisikan adegan-adegan kekerasan justru dapat dan sering meningkatkan agresivitas pada para penontonnya.

Hasil penelitian lainnya yang dilakukan oleh Sri Andayani (dalam Yhofita, 2002) menemukan bahwa prosentase acara televisi yang khusus menayangkan film kekerasan relatif besar. Film yang banyak mengandung adegan anti sosial sebanyak 58,4\% dari pada adegan pro sosial yang sebesar $41,6 \%$. Penelitian tersebut juga menemukan bahwa kategori agresivitas yang 
sering muncul berturut-turut adalah berkata kasar (38,56\%), memukul atau menendang $(28,46 \%)$ dan pengejekan $(11,44 \%)$.

Secara individual tayangan televisi yang tidak mendidik sangat berbahaya karena dengan adanya tayangan televisi yang berisikan adegan kekerasan membuat remaja cenderung berperilaku agresif.

\section{TUJUAN PENELITIAN}

Penelitian ini bertujuan untuk mengetahui hubungan antara minat terhadap tayangan kekerasan di televisi dengan perilaku agresif.

\section{METODE PENELITIAN}

Variabel tergantung, dalam penelitian ini adalah perilaku agresif. Perilaku agresi adalah bentuk perilaku menyerang dan menyakiti orang lain baik secara verbal maupun fisik. Sedangkan variabel bebasnya adalah minat terhadap tayangan kekerasan di televisi. Minat terhadap tayangan kekerasan adalah kecenderungan seseorang untuk tertarik dan senang pada tayangan kekerasan di televisi, antara lain : Smackdown, Heroes, Rambo,
Dragon Ball, olahraga tinju, dan Mission Impossible.

Penelitian ini dilakukan di MTs An-Najah II Sumenep Madura. Sampel yang digunakan sebanyak 87 siswa.

Alat ukur yang dipakai berupa angket perilaku agresif untuk mengetahui agresi fisik dan verbal serta angket minat terhadap tayangan kekerasan di televisi untuk mengetahui ketertarikan, kesenangan dan frekuensi subjek terhadap tayangan kekerasan.

Teknik pengambilan sampel pada penelitian ini menggunakan teknik incidental sampling, karena kelas yang akan dijadikan sampel ditentukan oleh pihak sekolah

\section{HASIL PENELITIAN DAN PEMBAHASAN}

Analisis terhadap hasil penelitian ini secara kuantitatif menunjukkan bahwa terdapat hubungan yang sangat signifikan antara variabel minat terhadap tayangan kekerasan di televisi dengan variabel perilaku agresif. Hasil ini mendukung hipotesis yang diajukan, yaitu ada hubungan antara 
minat terhadap tayangan kekerasan di televisi dengan perilaku agresif, dimana koefisien korelasi kedua variabel penelitian diperoleh nilai $\mathrm{r}=$ 0,383 dengan $p=0,002(p<0,010)$.

Hasil penelitian ini sesuai dengan pendapat yang dikemukakan oleh Fiedrich dan Stein (dalam Worchel \& Cooper, 1983) bahwa anak-anak yang menonton tayangan netral dan prososial dapat menurun agresivitasnya, sedang anak-anak yang menonton tayangan kekerasan dapat meningkat agresivitasnya. Begitu pula dengan yang dikemukakan oleh Parke, dkk (dalam Worchel \& Cooper, 1983), anakanak yang melihat tayangan kekerasan menunjukkan perilaku yang lebih agresif dibanding dengan anak-anak yang melihat tayangan netral.

Agresi ada atau terbentuk pada manusia sebagai hasil dari proses belajar dimana stimulusstimulus eksternal dan perkuatan atau reinforcement dilihat sebagai faktor-faktor yang menentukan dalam proses belajar atau pembentukan tingkah laku. Cara yang sangat penting dalam belajar sosial adalah tingkah laku tiruan atau imitasi. Proses belajar ini biasa disebut dengan pemodelan atau modelling. Demikian juga dengan perilaku agresi. Tingkah laku agresi bisa berupa tingkah laku fisik maupun verbal dan ditunjukkan melalui berbagai macam bentuk tingkah laku seperti menyerang orang lain, mengancam secara fisik atau verbal, menuntut orang lain, mencoba memaksa untuk memiliki benda-benda yang bukan miliknya.

Bandura berpendapat bahwa sebagian besar belajar yang dialami manusia tidak terbentuk dari konsekuensi-konsekuensi, melainkan manusia itu belajar dari suatu model. Seseorang belajar untuk menjadi agresif melalui penguatan yang diberikan pada keagresifan mereka dengan melihat orang lain memperagakan perilaku yang agresif. Setelah seorang anak menyaksikan peragaan agresif dari orang dewasa, maka dia cenderung ikut lebih agresif dalam berperilaku.

Kebanyakan model yang ditiru bukan hanya orang-orang yang kongkrit ada, tetapi juga modelmodel simbolis, seperti televisi atau 
buku-buku lainnya. Televisi yang hadir dengan lebih menonjolkan aspek hiburannya, tak jarang banyak yang menampilkan adegan kekerasan. Memukul, menendang, berucap kata-kata kotor dan sebagainya dan masyarakat kita justru menggemari tayangan tersebut. Sering terjadi bahwa proses peniruan memang tidak didasari oleh rasionalitas, sehingga orang yang menyaksikan kekerasan di televisi bisa menjadi ikut-ikutan agresif.

Agresivitas pada remaja dapat meningkat karena salah satunya dipengaruhi oleh minat remaja terhadap tayangan kekerasan di televisi. Dengan semakin seringnya remaja menonton tayangan kekerasan maka ia belajar untuk menjadi agresif. Sikap agresif diperoleh individu dari meniru suatu model dalam lingkungan sosial, dalam hal ini remaja meniru perilaku model yang mereka lihat pada tayangan televisi, yang sebagian besar mengandung unsur kekerasan. Dengan kata lain, menonton filmfilm yang berisikan adegan-adegan kekerasan justru dapat dan sering meningkatkan agresivitas pada para penontonnya.

\section{KESIMPULAN DAN SARAN}

Berdasarkan hasil penelitian ini dan pembahasan yang telah dilakukan, maka dapat disimpulkan bahwa :

Ada hubungan yang sangat signifikan antara minat terhadap tayangan kekerasan di televisi dengan perilaku agresif. Sehingga semakin tinggi minat siswa terhadap tayangan kekerasan di televisi maka semakin tinggi pula perilaku agresif siswa tersebut. Demikian pula sebaliknya, yaitu semakin rendah minat siswa terhadap tayangan kekerasan di televisi maka semakin rendah pula perilaku agresif siswa tersebut.

Berdasarkan hasil penelitian dan pembahasan yang dilakukan, maka dapat memberikan saran, antara lain :

1. Bagi orang tua, diharapkan dapat mendampingi anak ketika menonton terlebih lagi pada saat menonton tayangan-tayangan yang berisikan adegan kekerasan. Berikan pandangan 
lain dengan pandangan yang diberikan tayangan tersebut.

2. Bagi sekolah, yang merupakan lingkungan kedua setelah keluarga. Sekolah tidak hanya berfungsi sebagai tempat untuk mengajar ilmu saja, tetapi juga sebagai pembimbing bagi anak didiknya. Sebisa mungkin sekolah dapat mengadakan kegiatan bedah film tentang film kekerasan dan film non kekerasan serta jelaskan dampak positif maupun negatif dari kedua tayangan tersebut bagi anak didiknya.

3. Bagi media massa, hendaknya memiliki tanggung jawab sosial terhadap tayangan-tayangan yang disajikan kepada pemirsanya. Harus mempunyai komitmen untuk menayangkan tayangan-tayangan yang jauh dari unsur kekerasan. Kalaupun ada unsur kekerasan, sebaiknya ditayangkan pada saat anak-anak tidur. Kalaupun itu tayangan untuk anak-anak, tayangan tersebut harus dikemas tanpa kekerasan. Media massa harus mempunyai komitmen untuk perbaikan generasi.

4. Bagi pemerintah sebagai pemegang kebijakan, hendaknya kebijakan itu dapat dilaksanakan dengan konsekuen dan penuh tanggung jawab. Buat peraturanperaturan yang jelas mengenai tayangan, jam tayang dan beri sanksi-sanksi yang tegas pada media massa yang melanggar. Pemerintah juga dengan adanya lembaga sensor, sebaiknya setelah tayangan tersebut disensor, pemerintah pun harus mengawasi karena terkadang pemerintah kecolongan.

5. Bagi remaja, harus cerdas dalam memilih tayangan. Yang mana tayangan tersebut harus mempunyai dampak yang positif baik bagi perilaku maupun pemikiran-pemikiran. Pilihlah tayangan yang bermanfaat, jangan asal menonton.

\section{DAFTAR PUSTAKA}

Ahmadi, Abu \& Supriyono, W. 2004. Psikologi Belajar. Cet II. Jakarta : Rineka Cipta. 
Bandura, A. 1986. Social Learning Theory. New York : Englewood Cliffs Prentice Hall.

Baron, Robert A. and Byrne, D. (1991). Social Psychology : Under Standing Human Interaction $\left(6^{\text {th }}\right.$ ed). Boston : Allyn \& Bacan.

Berkowitz, L. 1995. Agresi : Sebab dan Akibatnya. Jilid I. Terjemahan Hartatni Woro Susiatni. Cetakan I. Jakarta : Pustaka Binaman Pressindo.

Bhatia, B. D. \& Safaya, R. N. 1990. Educational Psychology and Guidance. Delhi : Danpat Rai \& Sons Julludar.

Crow, L. D. \& A, Crow. 1979. Educational Psychology. New York : American Book Co.

Gerungan, W. A. 2000. Psikologi Sosial. Bandung : PT Eresco.

Gunarsa, S. D. 1985. Dasar dan Teori Perkembangan Anak. Jakarta: PT BPK Gunung Mulia.

Gunarsa, S. D. 1986. Psikologi Remaja. Jakarta : PT BPK Gunung Mulia.

Gunarsa, S. D. 2000. Psikologi Perkembangan Anak dan Remaja. Jakarta : Gunung Mulia.

Hadi, Sutrisno. 1993. Metodologi Research Jilid III. Yogyakarta : CV. Andi Offset.
Hergenhahn, B. R. and Matthew H. Olson. (1993). An Introduction to Theories of Learning. New Jersey : Prentice Hall, Inc

Hurlock, E. B. 1996. Psikologi Perkembangan : Suatu Pendekatan Sepanjang Rentang Kehidupan ( $5^{\text {th }}$ ed). Terjemahan Istiwidayanti. Jakarta : Penerbit Airlangga.

Kartono. 1985. Bimbingan Belajar di SMA dan Perguruan Tinggi. Jakarta : CV. Rajawali

Kiranawati, Indah. 1994. Minat Terhadap Pekerjaan dengan Kepuasan Kerja Pada Karyawan di PT "X" Sidoarjo. Skripsi S1. Tidak diterbitkan. Fakultas Psikologi Universitas Surabaya.

Koeswara, E. 1988. Agresi Manusia. Bandung : PT Eresco.

Monks, dkk. 1994. Psikologi Perkembangan : Pengantar dalam Berbagai Bagiannya. Yogyakarta : Gadjah Mada University Press.

Monks, dkk. 2002. Psikologi Perkembangan : Pengantar dalam Berbagai Bagiannya. Yogyakarta : Gadjah Mada University Press.

Santrock, J. W. 1995. Life Span development : Perkembangan Masa Hidup. Edisi V. Jakarta : Erlangga. 
Schaefer \& Lamm. 1998. Sociology $\left(6^{\text {th }}\right.$ ed). New York : Mc Graw Hill.

Shalahuddin, M.1990. Pengantar Psikologi Pendidikan. Surabaya : PT. Bina Ilmu.

Sukadji, Sutarlinah. 1995. Pengaruh Pola Asuh terhadap Perilaku Agresif Anak. Jurnal Psikologi, 1, 20-30. Yogyakarta : Fakultas Psikologi Universitas Gadjah Mada.

Super, D. E. \& Crites, J. O. 1965. Appraising Vocational Fitness. New York : Prentice Hall Inc.

Suryabrata, S. 1988. Metodologi Penelitian. Jakarta : CV Rajawali.

Suryabrata, S. 2005. Pengembangan Alat Ukur Psikologi. Yogyakarta : CV. Andi Offset.

Taylor, et al. 1994. Social Psychology $\left(8^{\text {th }}\right.$ ed). New Jersey : Englewood Cliffs Prentice Hall.

Walgito, Bimo. 1981. Psikologi Sosial Suatu Pengantar. Yogyakarta : Yayasan Penerbit Fakultas Psikologi Universitas Gadjah Mada.

Worchel, S. And Cooper, J. 1983). Understanding Social Psychology. 3rd ed. Homewood, Illinois : The Dorsey Press. 